\title{
Properties of neurofilament protein kinase
}

Danièle TORU-DELBAUFFE, Michel PIERRE, Jeanine OSTY, Françoise CHANTOUX and Jacques FRANCON Unité de Recherche sur la Glande Thyroide et la Régulation Hormonale, INSERM, 78 rue du Gl Leclerc, 94270 Bicêtre, France

Neurofilament (NF) protein kinase, partially purified from NF preparations [Toru-Delbauffe \& Pierre (1983) FEBS Lett. 162, 230-234], was found to be distinct from both the casein kinase present in NFs and the cyclic AMP-dependent protein kinase which is able to phosphorylate NFs. NF-kinase phosphorylated the three NF protein components. The amount of phosphate incorporated per molecule was higher for NF 200 than for NF 145 and NF 68. Other proteins present in the NF preparations were also used as NF-kinase substrates. Two of them might correspond to the myelin basic proteins with $M_{\mathrm{r}}$ values of 18000 and 21000 . Four other substrates in the NF preparation were not identified (respective $M_{\mathrm{r}}$ values $53000,55000,65000$ and $>300000$ ). NF kinase also phosphorylated two additional brain-cell cytoskeletal elements: GFAp and vimentin. Casein, histones and phosvitin, currently used as substrates for protein kinase assays, were very poor phosphate acceptors. Half-maximal NF-kinase activity was obtained at an NF protein concentration of about $0.25 \mathrm{mg} / \mathrm{ml}$ in heated, salt-washed, NF preparations. The specific activity was about $5 \mathrm{pmol}$ of ${ }^{32} \mathrm{P}$ incorporated $/ \mathrm{min}$ per $\mu \mathrm{g}$ of NF kinase preparation protein. ATP was a phospho-group donor $\left(K_{\mathrm{m}}\right.$ $8 \times 10^{-5} \mathrm{M}$ ), but GTP was not. NF-kinase activity remained stable at $65^{\circ} \mathrm{C}$ for more than $1 \mathrm{~h}$. The enzyme was not degraded by storage at $-20{ }^{\circ} \mathrm{C}$ for several months in a buffer containing $50 \%(\mathrm{w} / \mathrm{v})$ sucrose. Maximal activity was obtained with $5 \mathrm{mM}-\mathrm{Mg}^{2+}\left(\mathrm{Mg}^{2+}\right.$ could be replaced by $\left.\mathrm{Co}^{2+}\right) ; \mathrm{Zn}^{2+}$ and $\mathrm{Cu}^{2+}$ inhibited the reaction. NF-kinase was not dependent on cyclic AMP, cyclic GMP, $\mathrm{Ca}^{2+}$ or $\mathrm{Ca}^{2+}$ plus dioleoylglycerol and phosphatidylserine.

\section{INTRODUCTION}

Neurofilaments(NFs), which are intermediate filaments specifically present in neurons, can be phosphorylated in vivo and in vitro [for a review, see Lazarides (1982)]. NF phosphorylation is probably catalysed, at least in part, by protein kinases present in NF preparations (Lazarides, 1982; Nestler \& Greengard, 1983). These enzymes are known to phosphorylate the three protein components of NFs (NF 200, NF 145 and NF 68) (Lazarides, 1982; Nestler \& Greengard, 1983), but no effectors have yet been found for them.

Toru-Delbauffe \& Pierre (1983) reported previously that the protein kinases present in NF preparations could be separated into two activities: one, identified as casein kinase I $\left(\mathrm{CK}_{\mathrm{I}}\right)$, which did not phosphorylate NF preparations, and another, which did.

In the present paper we report the properties of the latter enzyme, which we named 'NF-protein kinase' or 'NF-kinase', and compare it with $\mathrm{CK}_{\mathrm{I}}$ and cyclic AMP-dependent protein kinase.

\section{MATERIALS AND METHODS}

\section{Materials}

Cyclic AMP, cyclic GMP, ATP, GTP, leupeptin, Tos-Arg-OMe, PMSF, dioleoylglycerol ('diolein') phosphatidylserine, phosvitin, histones, cyclic AMP-dependent protein kinase and calf intestinal alkaline phosphatase (type VII) were purchased from Sigma; $\left[\gamma^{-32} \mathrm{P}\right] \mathrm{ATP}$ and $\left[\gamma^{-32}\right.$ P]GTP were obtained from The Radiochemical Centre, Amersham, Bucks., U.K.; P11 phosphocellulose was from Whatman; acrylamide and bisacrylamide were from Eastman Kodak; antibody against GFAp was from Sanbio (Holland) and ${ }^{125}$ I-labelled antibody (sheep anti-mouse IgG) was from The Radiochemical Centre.

\section{Neurofilament preparation}

The procedure described in Toru-Delbauffe \& Pierre (1983) was employed with a single modification. All the buffers used contained leupeptin $(2 \mathrm{mg} / \mathrm{ml})$, Tos-Arg$\mathrm{OMe}(0.5 \mathrm{mg} / \mathrm{ml})$ and $2 \mathrm{mM}-\mathrm{PMSF}$.

\section{Isolation of the astrocyte cytoskeletons}

Cytoskeletons were isolated by the method of Chiu \& Norton (1982), from astrocyte-enriched secondary cell cultures, grown as previously described (Lennon et al., 1983).

\section{Microtubule-associated protein (MAP) preparation}

Brain microtubules were purified by a slightly modified temperature-dependent assembly-disassembly procedure (Shelanski et al., 1973).

Large amounts of MAPs were obtained by thermodenaturation of the purified microtubules in the presence of high salt concentrations (Fellous et al., 1977).

\section{Extraction of protein kinase activities from NF preparations}

The procedure was described in Toru-Delbauffe \& Pierre (1983).

\section{Phosphocellulose chromatography}

Extract containing NF-kinase was applied to a phosphocellulose column $(0.9 \mathrm{~cm} \times 5 \mathrm{~cm})$ pre-equili-

Abbreviations used: NF(s), neurofilament(s); MAP, microtubule-associated protein; GFAp, glial fibrillary acidic protein; CK $_{1}$, casein kinase I; Tos-Arg-OMe, tosyl-L-arginine methyl ester; PMSF, phenylmethanesulphonyl fluoride; Tos-Phe- $\mathrm{CH}_{2} \mathrm{Cl}, \mathrm{N}$-tosyl-L-phenylalanylchloromethane ('TPCK'); Tos-Lys- $\mathrm{CH}_{2} \mathrm{Cl}$, tosyl-L-lysylchloromethane ('TLCK'). 
brated with buffer (50 mM-Tris/HCl/2 mM- $\mathrm{MgCl}_{2}$ / $150 \mathrm{~mm}-\mathrm{KCl}$, pH 7.1). The column was washed with the same buffer and the protein kinase activities were eluted with a linear gradient of $\mathrm{KCl}(150-800 \mathrm{mM})$. Fractions were assayed for NF kinase activity (see below) and for casein activity (Toru-Delbauffe \& Pierre, 1983). The eluted NF-kinase was concentrated by dialysis

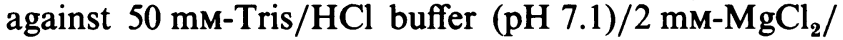
$50 \mathrm{~mm}-\mathrm{KCl} / 50 \%$ (w/v) sucrose.

\section{Protein kinase assay (standard conditions)}

The salt-washed NFs ( $2 \mathrm{mg}$ of protein $/ \mathrm{ml}$ ) to be used as substrate were preincubated for $5 \mathrm{~min}$ at $50^{\circ} \mathrm{C}$ just before protein kinase assay (see the Results section).

Assays were performed in $50 \mathrm{~mm}-$ Mes and $5 \mathrm{~mm}$ $\mathrm{MgCl}_{2}, \mathrm{pH} 6.5$, containing $0.5 \mathrm{mg}$ of proteins (NFs, or other proteins when indicated)/ml, 50-100 $\mu \mathrm{M}-\left[\gamma^{-32} \mathrm{P}\right]-$ ATP or $\left[\gamma^{32} \mathrm{P}\right] \mathrm{GTP}(1-2 \mu \mathrm{Ci} /$ assay) and portions of enzymic fraction, making a total volume of $120 \mu \mathrm{l}$. The reaction was initiated by the addition of the nucleotide. Incubation proceeded at $30^{\circ} \mathrm{C}$ for $3 \mathrm{~min}$. When the incubation time was longer than $3 \mathrm{~min}$, proteinase inhibitors $(4 \mu \mathrm{g}$ of leupeptin $/ \mathrm{ml}, 1 \mu \mathrm{g}$ of trypsin inhibitor $/ \mathrm{ml}, 1 \mathrm{~mm}$-benzamidine, $0.4 \mu \mathrm{g}$ of antipain $/ \mathrm{ml}$, $10 \mathrm{~mm}-\mathrm{PMSF}, 0.1 \mathrm{~mm}-\mathrm{Tos}-\mathrm{Phe}-\mathrm{CH}_{2} \mathrm{Cl}$ and $0.01 \mathrm{~mm}$-TosLys- $\mathrm{CH}_{2} \mathrm{Cl}$ were added. Incorporation of radioactivity was monitored by spotting $50 \mu \mathrm{l}$ aliquots of reaction mixture on to squares of Whatman $3 \mathrm{~mm}$ filter paper. The filters were then washed and counted for radioactivity as previously described (Toru-Delbauffe \& Pierre, 1983).

NF-kinase was also assayed in $1 \mathrm{~mm}$-potassium phosphate buffer, pH 7, containing $50 \mathrm{mm-glycerophos-}$ phate, $0.3 \mathrm{~mm}$-EGTA and $5 \mathrm{~mm}$-magnesium acetate, but its activity was lower under these conditions.

\section{Polyacrylamide-gel electrophoresis, autoradiography and immunoblotting}

NFs (or other proteins) were phosphorylated as described above by using $5 \mu \mathrm{Ci}$ of $\left[\gamma^{-32} \mathrm{P}\right] \mathrm{ATP}$. Where indicated, NFs were pretreated with alkaline phosphatase as described by Julien \& Mushynski (1982). Incubation was terminated by the addition of concentrated sample buffer. SDS/polyacrylamide-gel electrophoresis was performed as described by Laemmli (1970) with the acrylamide concentrations indicated in the Figures. Each sample loaded on the gels contained 10-30 $\mu \mathrm{g}$ of protein. The gels were stained with Coomassie Blue and dried. Gel autoradiography was carried out on Kodak X-Omat $R$ film with an intensifying screen.

After SDS/polyacrylamide-gel electrophoresis, proteins were electrophoretically transferred to nitrocellulose sheets for immunoblotting (Towbin et al., 1979). The sheets were then incubated with a monoclonal antibody against human GFAp (GFAp-6F2; 1:50 dilution); the second ${ }^{125}$ I-labelled antibody was sheep anti-mouse IgG. The nitrocellulose sheets were washed as described by Towbin et al. (1979) and autoradiographed.

\section{Determination of phosphate incorporation}

Electrophoregrams of ${ }^{32} \mathrm{P}$-labelled NF preparations were scanned after staining. The amount of protein in each band was estimated by comparison with serum albumin and phosphorylase subunit markers. The incorporated radioactive phosphate was measured by cutting and counting the bands from the dried, stained, polyacrylamide gel. The corresponding number of mol of phosphate was calculated from the specific radioactivity of ATP.

\section{RESULTS AND DISCUSSION}

The NF-kinase purified by phosphocellulose chromatography (Toru-Delbauffe \& Pierre, 1983) showed one major polypeptide with an $M_{\mathrm{r}}$ of 40000 and one minor band $\left(M_{\mathrm{r}}>200000\right)$ on SDS/polyacrylamide-gel electrophoresis (Fig. 1). However, it was not possible to ascertain which one of these polypeptides corresponds to the NF kinase and which is a contaminant. The NF-kinase preparation did not autophosphorylate (Fig. 1), and its specific activity was generally about $5 \mathrm{pmol}$ of ${ }^{32} \mathrm{P} / \mathrm{min}$ per $\mu \mathrm{g}$ of protein with NF preparations as substrate.

Attempts to further purify the NF kinase on other resins (DEAE-cellulose, CM-Sephadex, hydroxyapatite...) after phosphocellulose chromatography have failed. The enzyme activity was lost during subsequent purification steps.

NF-kinase could be stored at $-20^{\circ} \mathrm{C}$ for several months in a buffer containing $50 \mathrm{~mm}$-Tris $/ \mathrm{HCl} / 2 \mathrm{~mm}$ $\mathrm{MgCl}_{2} / 50 \mathrm{~mm}-\mathrm{KCl} / 50 \%$ (w/v) sucrose, $\mathrm{pH} 7.4$, with no loss of activity.

Heating the partially purified enzyme for $5 \mathrm{~min}$ at temperatures between 40 and $85^{\circ} \mathrm{C}$ did not modify its activity. NF-kinase is fairly stable on heating, since it can be incubated at $65^{\circ} \mathrm{C}$ for $1 \mathrm{~h}$ without any loss of activity. This property can be used to destroy other enzymic activities which might be present in the preparations.

The measurement of NF-kinase activity was improved by incubating the salt-washed NF preparations used as substrate at $50{ }^{\circ} \mathrm{C}$ for $5 \mathrm{~min}$ before assay. This treatment decreased residual kinase activity by $80 \%$ without impairing the phosphorylation of the NF proteins by solubilized enzyme (Table 1). The SDS/polyacrylamidegel-electrophoretic staining patterns of preparations heated at $50^{\circ} \mathrm{C}$ were no different from those of unheated NFs (Fig. 1). The same polypeptides were phosphorylated both before and after heating at $50^{\circ} \mathrm{C}$ for $5 \mathrm{~min}$ (Fig. 1). Incubation at $55^{\circ} \mathrm{C}$ completely inactivated residual kinase activity, but also suppressed the capacity of NFs to be phosphorylated.

It thus appears that the NF-kinase activity which remains associated with the NFs is much more thermosensitive than is solubilized NF-kinase. There are two possible explanations for this difference. First, they may be two distinct forms of NF-kinase, one of which is thermolabile and is strongly bound to NF preparation and another which is soluble and heat-stable. Second there is a single NF-kinase whose activity is modified by its environment. At this time we are unable to choose between these hypotheses.

In order to proceed with NF-kinase characterization we tested its activity with different substrates and effectors. Fig. 2 shows the NF-kinase activity observed in the presence of $\mathrm{Mg}^{2+}(0.1-10 \mathrm{mM})$. Activity was optimal at $5 \mathrm{~mm}$. As shown in Table $2, \mathrm{Mg}^{2+}$ was fully replaced by $\mathrm{Co}^{2+} . \mathrm{Ca}^{2+}$ could not replace $\mathrm{Mg}^{2+}$, but did not inhibit NF-kinase when $\mathrm{Mg}^{2+}$ was present. Other bivalent cations, such as $\mathrm{Zn}^{2+}$ and $\mathrm{Cu}^{2+}$, inhibited NF-kinase activity in the presence of $\mathrm{Mg}^{2+}$.

NF-kinase was not activated by cyclic AMP, cyclic GMP or $\mathrm{Ca}^{2+}$, or by $\mathrm{Ca}^{2+}$ plus phosphatidylserine and dioleoylglycerol. These compounds were examined at concentrations that have been shown to be effective with 


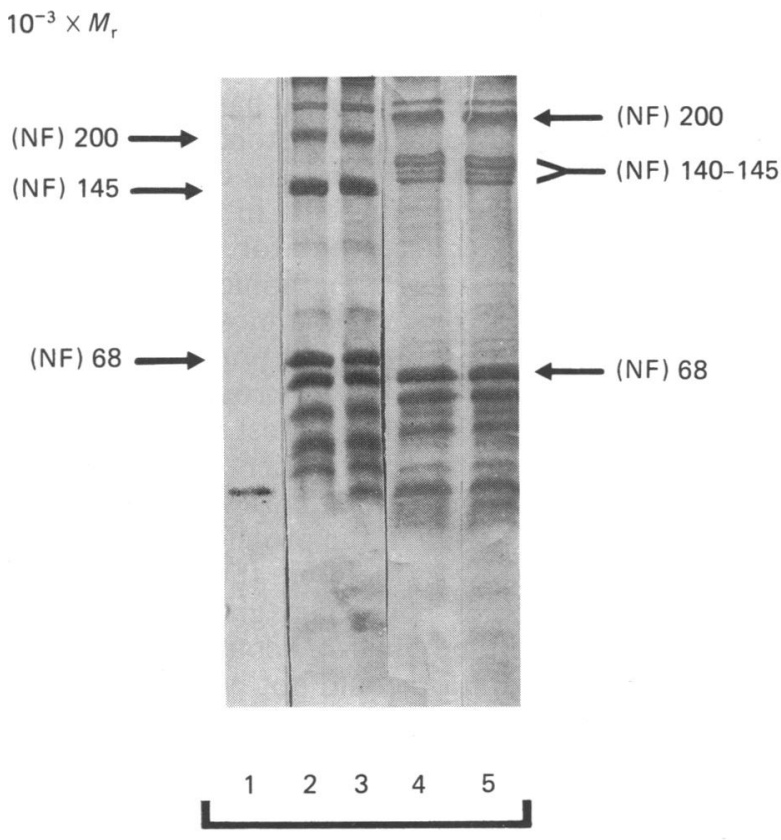

(a)

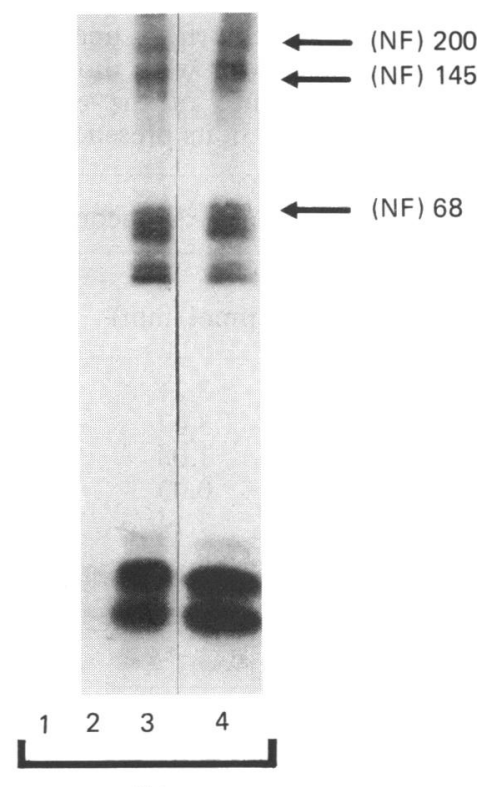

(b)

Fig. 1. Effect of temperature on the protein composition and phosphorylation of salt-washed NFs

(a) Salt-washed NFs were incubated in $10 \mathrm{~mm}$-sodium phosphate (pH 6.5)/0.85 $\mathrm{M}$-sucrose for $5 \mathrm{~min}$ at $50{ }^{\circ} \mathrm{C}$. Control preparations were not heated. They were analysed by SDS/polyacrylamide-gel electrophoresis on $8.5 \%$-acrylamide/0.23\%bisacrylamide $(2,3)$ or $15 \%$-acrylamide/0.1\%-bisacrylamide $(4,5)$ gels and stained with Coomassie Blue. NF kinase also was analysed on $8.5 \%$-acrylamide $/ 0.23 \%$-bisacrylamide gels (1). (b) Salt-washed NFs were preincubated in 10 mM-sodium phosphate (pH 6.5)/0.85 M-sucrose for $5 \mathrm{~min}$ at $50^{\circ} \mathrm{C}(2,3)$ or left unheated (4). After this preincubation, NFs were incubated with [ $\left.\gamma^{32} \mathrm{P}\right] \mathrm{ATP}$ under standard conditions in the presence $(3)$ or the absence $(2,4)$ of NF-kinase. NF kinase alone was also incubated with $\left[\gamma-{ }^{32} \mathrm{P}\right] \mathrm{ATP}$ under standard conditions (1). After this the samples were analysed on $15 \%$ acrylamide $/ 0.1 \%$ bisacrylamide gels, which were then stained and autoradiographed.

Table 1. Thermal inactivation of residual NF-kinase activity in NFs after salt extraction

Salt washed NFs were heated in $10 \mathrm{~mm}$-sodium phosphate (pH 6.5)/0.8 $\mathrm{M}$-sucrose for $5 \mathrm{~min}$ at the indicated temperature. They were then used as substrates in NF-kinase assays. ${ }^{32} \mathbf{P}$ incorporation was measured under standard conditions.

\begin{tabular}{lccc} 
NF heating $\begin{array}{l}\text { Nonditions } \\
\text { con }\end{array}$ & \multicolumn{2}{c}{${ }^{\circ} \mathrm{C}$ incorporation into NFs (c.p.m.) } & Ratio $\frac{+}{-}$ \\
\cline { 2 - 3 } & - NF kinase & + NF kinase & \\
\hline None & 8090 & 11552 & 1.43 \\
40 & 4741 & 6947 & 1.47 \\
45 & 2022 & 8088 & 4.00 \\
50 & 1336 & 6013 & 4.50 \\
55 & 0 & 126 & - \\
\hline
\end{tabular}

their respective protein kinase. The failure of NF-kinase to respond to cyclic nucleotides was also observed in autophosphorylation studies of NF preparations (Eagles \& Gilbert, 1979; Runge et al., 1981b; Julien et al., 1983; Shecket \& Lasek, 1982).

The phosphate donors and phosphate acceptors currently used for protein kinase assays were also tested. NF-kinase used ATP as a phosphate donor, exhibiting a $K_{\mathrm{m}}$ value of about $8 \times 10^{-5} \mathrm{M}$. GTP, however, was not a phosphate donor for this enzyme (Table 3). Fig. 3 shows

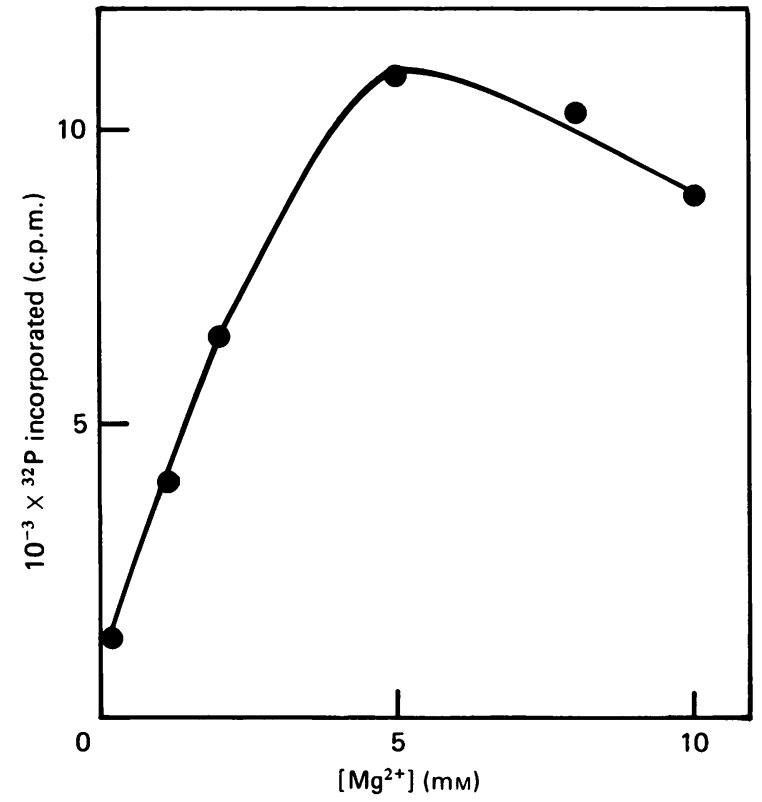

Fig. 2. Dependence of NF-kinase activity on $\mathbf{M g}^{2+}$ concentration

${ }^{32} \mathrm{P}$ incorporation into NFs was measured under standard conditions, in the absence or presence of NF-kinase at various $\mathrm{Mg}^{2+}$ concentrations. NF-kinase activity was calculated by subtracting the values obtained in the absence of the enzyme from those measured in its presence. 


\section{Table 2. Cation specificity of NF kinase}

Protein kinase assays were performed under standard conditions, except that the cations were those indicated. Values measured in the absence of the enzyme were subtracted from those obtained in its presence.

${ }^{32} \mathbf{P}$ incorporated

Bivalent cation

[\% of control $\left.(\mathrm{pmol} / \mathrm{min}) \quad\left(5 \mathrm{mM}-\mathrm{Mg}^{2+}\right)\right]$

\begin{tabular}{lrr}
\hline $\mathrm{Mg}^{2+}(5 \mathrm{mM})$ & 3.21 & 100 \\
$\mathrm{Co}^{2+}(5 \mathrm{mM})$ & 3.07 & 96 \\
$\mathrm{Mn}^{2+}(5 \mathrm{mM})$ & 1.08 & 30 \\
$\mathrm{Ca}^{2+}(5 \mathrm{mM})$ & 0.03 & 0 \\
$\mathrm{Mg}^{2+}(5 \mathrm{mM})+\mathrm{Ca}^{2+}(5 \mathrm{mM})$ & 3.14 & 98 \\
$\mathrm{Mg}^{2+}(5 \mathrm{mM})+\mathrm{Zn}^{2+}(2 \mathrm{mM})$ & 0.85 & 26 \\
$\mathrm{Mg}^{2+}(5 \mathrm{mM})+\mathrm{Cu}^{2+}(2 \mathrm{mM})$ & 0.02 & 0
\end{tabular}

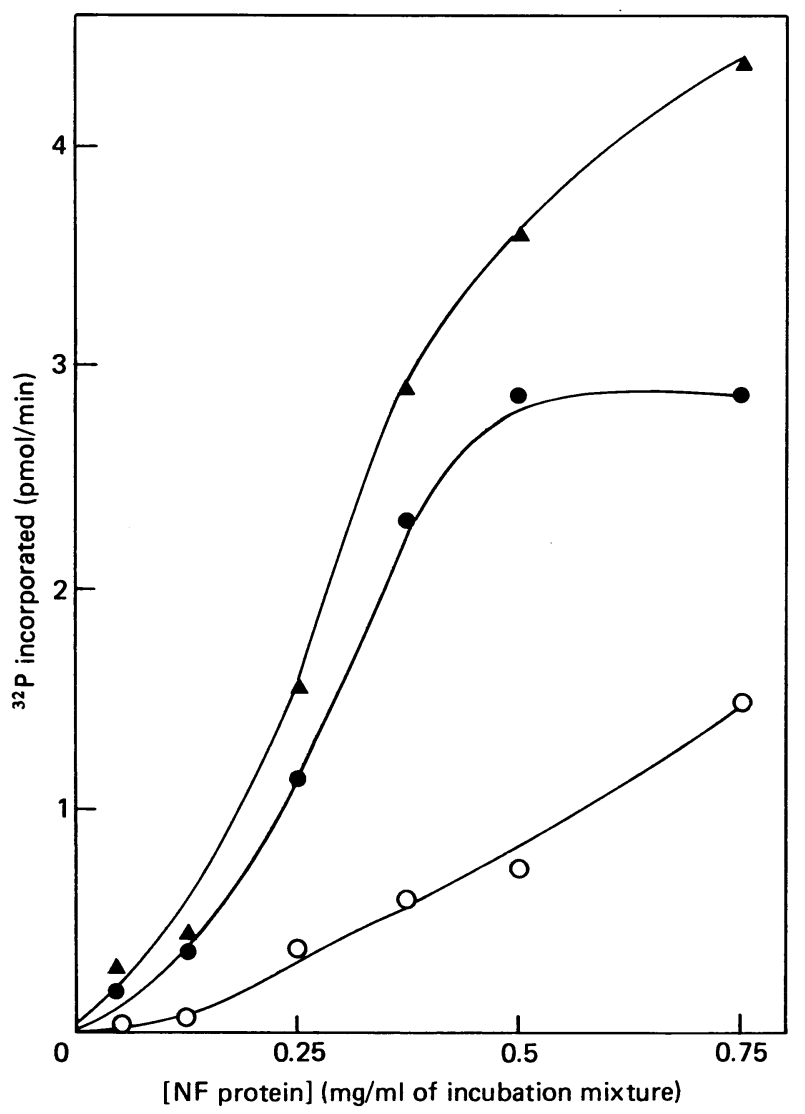

Fig. 3. Dependence of NF-kinase activity on the NF concentration

${ }^{32} \mathrm{P}$ incorporation was measured under standard conditions in the absence $(O)$ or presence $(\Delta)$ of NF-kinase, at various concentrations of salt-washed and heated NFs. NF-kinase activity ( $O$ ) was calculated by subtracting the value measured in the absence of the enzyme from those measured in its presence.

the activity of NF-kinase at various NF concentrations. Half-maximal activity was obtained at about $0.25 \mathrm{mg}$ of protein $/ \mathrm{ml}$. Its specific activity was $10 \mathrm{pmol}$ of phosphate incorporated $/ \mathrm{min}$ per $\mu \mathrm{g}$ of NF-kinase preparation protein. Of the proteins currently used as phosphate acceptors for protein kinase assays, NF-kinase did not effectively phosphorylate either acidic proteins such as phosvitin and casein, or basic proteins such as protamine, whole histones and histone subfractions (Table 3).

The three NF proteins components (NF 200, NF 145 and NF 68) present in NF preparations were all phosphate acceptors for NF-kinase (Figs. 1 and 4). Though autoradiographic patterns showed that the NF 145 band was the most ${ }^{32}$ P-labelled, the number of phosphate groups incorporated in vitro by the NF-kinase per molecule of NF protein was 2-3 times higher in NF 200, the protein most phosphorylated in vivo (Jones \& Williams, 1982; Julien \& Mushynski, 1982), than in NF 145, and 10-20 times higher in NF 200 than in NF 68 (Table 4). Of all the proteins present in NF-preparation, NF 200 was the one that incorporated the greatest number of phosphate groups per molecule of protein (except the 65000- $M_{\mathrm{r}}$ component, for which phosphate incorporation could not be determined). The amount of phosphate incorporated by the NF-kinase into these proteins appears low when compared with the total phosphate contents of these proteins (Jones \& Williams, 1982; Julien \& Mushynski, 1982). It is possible that the amount of NF-kinase available in our experiments did not permit phosphorylation of all the potential sites in the incubation time (up to $2 \mathrm{~h}$ ) during which we could prevent proteolysis with a mixture of proteinase inhibitors. It is also likely that the NF proteins may be phosphorylated by different protein kinases in vivo on

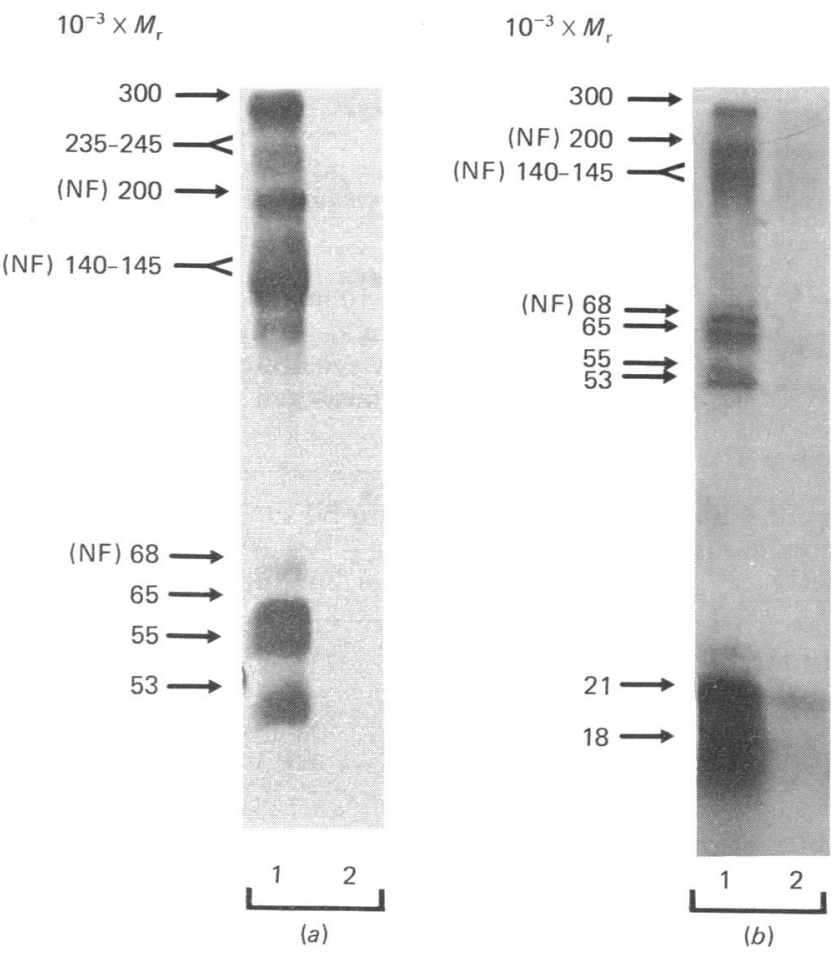

Fig. 4. Identification of the neurofilament proteins phosphorylated by NF-kinase

Heated salt-washed NFs were incubated with $\left[\gamma^{-32} \mathrm{P}\right] \mathrm{ATP}$ in the presence (1) or absence (2) of NF-kinase and analysed on $8.5 \%$-acrylamide $/ 0.23 \%$-bisacrylamide $(a)$ or $15 \%$-acrylamide $/ 0.1 \%$-bisacrylamide (b) gels. Electrophoresis was stopped when the dye marker reached the end of the gel. The gels were autoradiographed. 
Table 3. Comparative substrate specificity of NF-kinase and other protein kinases

Protein kinase assays were performed under standard conditions, except that the phosphate acceptor, phosphate donor and protein kinases were those indicated. The concentrations of all the substrates in the reaction mixture was $0.5 \mathrm{mg} / \mathrm{ml}$. Abbreviation used cAMP-PK, cyclic AMP-dependent protein kinase.

\begin{tabular}{|c|c|c|c|}
\hline \multirow{2}{*}{$\begin{array}{l}\text { Phosphate } \\
\text { acceptor }\end{array}$} & \multicolumn{3}{|c|}{${ }^{32} \mathrm{P}$ incorporated $(\mathrm{pmol} / \mathrm{min})$} \\
\hline & NF-kinase & cAMP-PK & Casein kinase I \\
\hline \multicolumn{4}{|l|}{ Donor ATP } \\
\hline Whole histone & 0.17 & & $0.09(8 \%)$ \\
\hline $\begin{array}{l}\text { Lysine-rich histone } \\
\text { (III Sigma) }\end{array}$ & 0.2 & & \\
\hline \multicolumn{4}{|l|}{ Histone } \\
\hline $\mathrm{H} 1$ & 0.18 & & \\
\hline $\mathbf{H} 2 \mathrm{~A}$ & 0.06 & & \\
\hline $\mathrm{H} 2 \mathrm{~B}$ & $0.03(0.8 \%)$ & $1(100 \%)$ & \\
\hline H3 & 0.06 & $1(100)$ & \\
\hline Protamine sulphate & 0.12 & & \\
\hline Casein & 0.1 & & $1.2(100 \%)$ \\
\hline Phosvitin & 0.07 & & \\
\hline NF & $3.85(100 \%)$ & $0.3(30 \%)$ & $0.08(6.5 \%)$ \\
\hline \multicolumn{4}{|l|}{ Donor GTP } \\
\hline NF & $0.35(9 \%)$ & & \\
\hline
\end{tabular}

Table 4. Stoichiometry of phosphorylation of neurofilament proteins by NF-kinase

NF preparations were phosphorylated by NF-kinase under standard conditions for $2 \mathrm{~h}$. The ratio ${ }^{\circ 32} \mathrm{P}(\mathrm{mol} / \mathrm{mol}$ of protein)' was determined as described in the Materials and methods section.

\begin{tabular}{lc}
\hline$M_{\mathrm{r}}$ & 32P (mol/mol of protein) \\
\hline$>300000$ & 0.10 \\
$200000(\mathrm{NF} \mathrm{200)}$ & 0.50 \\
150000 (NF 150) & 0.19 \\
68000 (NF 68) & 0.04 \\
65000 & $\mathrm{NCBS} *$ \\
55000 & 0.16 \\
53000 & 0.06 \\
21000 & 0.09 \\
18000 & 0.28 \\
${ }^{*}$ No Coomassie Blue Staining. & \\
\hline
\end{tabular}

different sites, since it has been shown that a cyclic AMP-dependent protein kinase (Leterrier et al., 1981) and a calmodulin-dependent protein kinase (Lou Vallano et al., 1985) can also phosphorylate NF proteins in vitro. Thus, despite the presence of several phosphorylation sites on NF proteins, only few of them might be available to NF kinase. Another possibility is that the sites recognized by the NF-kinase had already been phosphorylated in vivo. This possibility was tested by treating NFs with alkaline phosphatase as described by Julien \& Mushynski (1982) before incubation with NF-kinase. No additional incorporation was observed (results not shown).

Analysis on an SDS/15\%-(w/v)-polyacrylamide gel, indicated that the NF 145 appeared to be composed of four forms, with $M_{\mathrm{r}}$ values ranging from 140000 to 145000 (Fig. 1a). Goldstein et al. (1983) and Nixon et al.
(1982) have previously shown the great microheterogeneity of both the NF 145 and NF 200 subunits. The latter authors reported that the above polypeptides in the $140000-145000-M_{r}$ range included at least three components, which were differently distributed along the axon. A large autoradiographic band seemed to spread over the four Coomassie Blue-stained components (Figs. 1 and 4), but we could not determine whether all four of the components had incorporated ${ }^{32} \mathrm{P}$.

Several other polypeptides presents in the NF preparations were also phosphorylated to various extents by NF-kinase (Table 4; Fig. 4, arrows). They included: (i) a protein of $M_{\mathrm{r}}>300000$ that was also previously observed in NF preparations (Burridge et al., 1982) and whose the electrophoretic migration did not correspond to that of $\mathrm{MAP}_{2}$ (results not shown); (ii) a weakly labelled protein, probably fodrin, which migrated as doublet of $M_{\text {r }} 235000-245000$ and was identified by an antibody directed against spectrin (Burridge et al., 1982; present results not shown); (iii) a highly phosphorylated component $\left(M_{r} 65000\right)$; the absence of Coomassie Blue staining at the level of this component prevented calculation of the number of phosphates group incorporated; Liem et al. (1984) claimed that an antiserum directed against polypeptide with an $M_{\mathrm{r}}$ of 66000 isolated from NFs recognized one $\tau$ protein; however, according to our results, the polypeptide whose $M_{\mathrm{r}}$ was $65000 \mathrm{did}$ not co-migrate on SDS/polyacrylamide gel with any of the $\tau$ components (results not shown); (iv) two polypeptides with $M_{\mathrm{r}}$ values of 55000 and 53000 ; the $55000-M_{\mathrm{r}}$ polypeptide incorporates as much phosphate as does NF 150 (Table 4); polypeptides in the 40000$65000-M_{\mathrm{r}}$ range which are co-purified with NFs may exist in vivo according to Carden \& Eagles (1983); however, Autilio-Gambetti et al. (1981) and Chin et al. (1983) believe that they might be proteolytic products of the NF 145 and NF 200 proteins; these suggestions were confirmed by Brown et al. (1983), who showed that two polypeptides with $M_{\mathrm{r}} 65000$ and 53000 were recognized 
by anti-(NF 140-145) and anti-(NF 68) sera; (v) two low- $M_{\mathrm{r}}$ polypeptides; from their $M_{\mathrm{r}}$ values of 21000 and 18000 they may be tentatively identified as two of the four basic myelin proteins in rat brain (Kelly \& Luttges 1976; Brown et al., 1980); the number of phosphates groups incorporated into the $18000-M_{\mathrm{r}}$ component was between the values determined for NF 200 and NF 150 (Table 4).

These observationsillustrate the specificity of NF-kinase and distinguish it from casein kinase and from cyclic AMP-dependent protein kinase. Indeed, as indicated above, casein and histones are poor substrates for the NF-kinase and there is no known activator for this enzyme. Thecasein kinase associated with NFpreparations does not phosphorylate NF proteins (Table 3 and Fig. 5) and the cyclic AMP-dependent protein kinase, which also phosphorylates the triplet proteins and several polypeptides in NF preparations (Table 3, Fig. 5), preferentially uses histones as substrates. Furthermore, the best substrate of the cyclic AMP-dependent protein kinase was NF 145 (Leterrier et al., 1981; Zimmerman \& Schlaepfer 1985). The other polypeptides in NF preparations that were phosphorylated by NF-kinase were bad substrates for the cyclic AMP-dependent protein kinase, particularly the $65000-M_{\mathrm{r}}$ protein. Conversely, at least two components of the NF preparations (Fig. 5) that were phosphorylated by the cyclic AMP-dependent protein kinase were not used as substrates by NF-kinase.

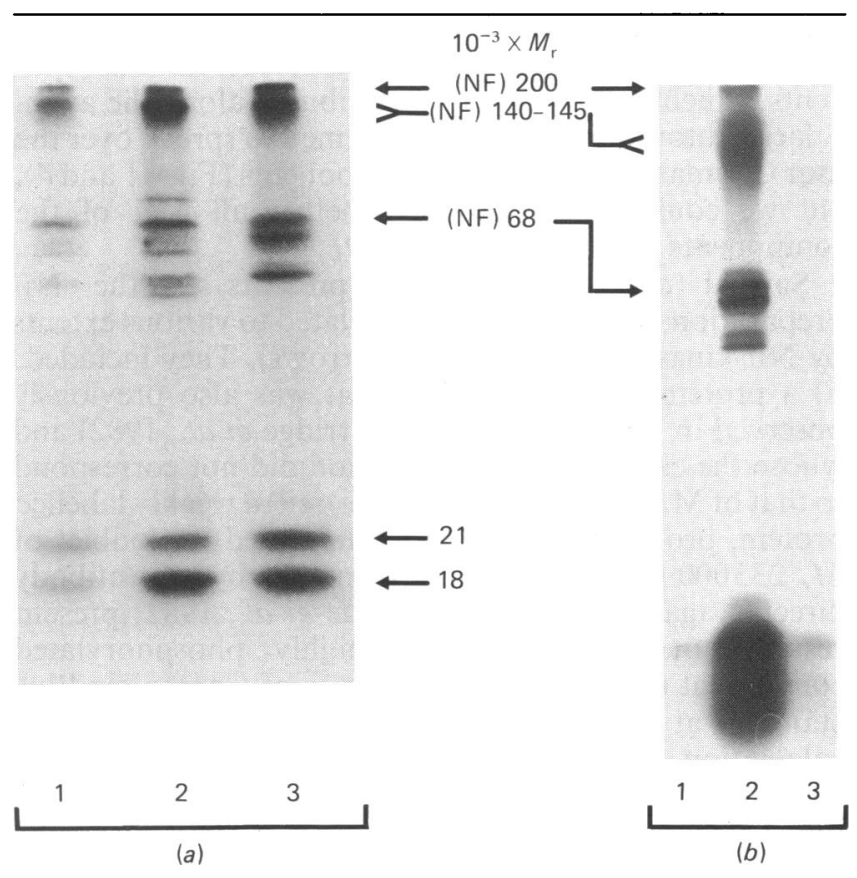

Fig. 5. Phosphorylation of NFs by various protein kinases

Heated salt-washed NFs were incubated and analysed as described in the legend to Fig. 4(b). (a) Comparison of NF-kinase and cyclic AMP-dependent protein kinase (both enzymes incorporated $3 \mathrm{pmol}$ of phosphate/min into NFs under standard conditions). 1, without protein kinase; 2, cyclic AMP-dependent protein kinase; 3, NF-kinase. (b) Comparison of NF-kinase (same activity as in $a$ ) and casein kinase I (the enzyme incorporated $1.5 \mathrm{pmol}$ of phosphate/ min into casein under standard conditions). Casein kinase I was prepared as described previously (Toru-Delbauffe \& Pierre, 1983). 1, without protein kinase; 2, NF-kinase; 3, casein kinase $\mathrm{I}$.
The ability of NF-kinase to phosphorylate the cytoskeleton of cultured astrocytes, which contain GFAp and vimentin (Chiu et al., 1981), was examined, since several authors have described structural analogies between the various intermediate-filament proteins (Geisler et al., 1982; Geisler, 1983; Steinert et al., 1983). The $51000-M_{\mathrm{r}}$ polypeptide identified as GFAp by using a monoclonal antibody (Fig. 6) was phosphorylated by NF-kinase, as were the $57000-M_{\mathrm{r}}$ polypeptide, vimentin, and other unidentified proteins.

It has also been suggested that microtubules might be associated with NFs in neurons (Runge et al., 1981a; Hirokawa, 1982; Leterrier et al., 1982; Minami et al., 1982; Nagele \& Roisen, 1982; Pachter et al., 1984; Aamodt \& Williams, 1984). We therefore attempted to phosphorylate the MAPs by NF-kinase. Preliminary observations indicated that the NF-kinase preparations could phosphorylate $\mathrm{MAP}_{2}$ and $\tau_{1}$ but, in contrast with the phosphorylation of NF proteins, they were no longer phosphorylated by NF-kinase which had been heat-treated (as described above).

The role of NF phosphorylation remains unknown. It might be involved in regulating NF-subunit assembly or it might mediate interactions between NFs and other cell organelles. The functions of NFs will probably have to be clarified before the biological role of this phosphoryla-

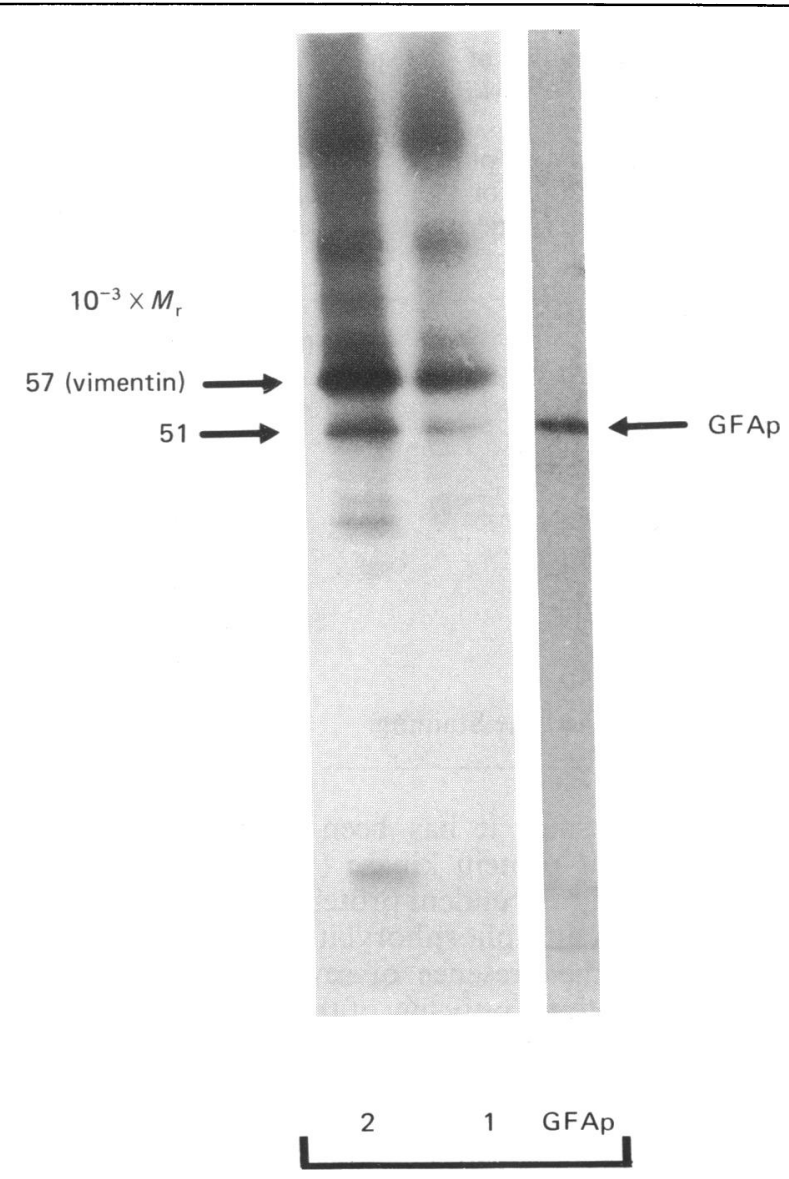

Fig. 6. Cytoskeletal brain proteins phosphorylated by NF-kinase

Astrocyte cytoskeletons $(1 \mathrm{mg} / \mathrm{ml})$ were incubated with $\left[\gamma-{ }^{32}\right.$ P]ATP in the absence (1) or presence (2) of NF-kinase and analysed on $15 \%$-acrylamide $/ 0.1 \%$-bisacrylamide gels and autoradiographed. GFAp was detected by a monoclonal antibody. 
tion can be understood. Although we have not identified any effector for NF-kinase, one possible approach to the identification of the mechanisms regulating the activity of this enzyme might be to examine the effect of extracellular signals, possibly hormonal, on NF phosphorylation in cell cultures.

We thank Mrs L. A. Pradel (Institut de Biologie PhysicoChimique, Paris) for a gift of the anti-spectrin serum, and Mrs A. Guedec and Mr M. Bahloul for the preparation of this manuscript.

\section{REFERENCES}

Aamodt, E. J. \& Williams, R. C. (1984) Biochemistry 23, 6023-6031

Autilio-Gambetti, L., Velasco, M. E., Sipple, J. \& Gambetti, P. (1981) J. Neurochem. 37, 1260-1265

Brown, B. A., Strocchi, P., Nixon, R. A. \& Marotta, C. A. (1980) Trans. Am. Soc. Neurochem. 11, 26-30

Brown, B. A., Majocha, R. E., Staton, D. M. \& Marotta, C. A. (1983) J. Neurochem. 40, 299-308

Burridge, K., Kelly, T. \& Mangeat, P. (1982) J. Cell. Biol. 95, 478-486

Carden, M. J. \& Eagles, P. A. (1983) Biochem. J. 215, 227-237

Chin, T. K., Eagles, P. A. M. \& Maggs, A. (1983) Biochem. J. 215, 239-252

Chiu, F. C., Norton, W. T. (1982) J. Neurochem. 39, 1252-1260

Chiu, F. C., Norton, W. T. \& Fields, K. L. (1981) J. Neurochem. 37, 147-155

Eagles, P. A. M. \& Gilbert, D. S. (1979) J. Physiol. (London) 287, 10-15

Fellous, A., Francon, J., Lennon, A. M. \& Nunez, J. (1977) Eur. J. Biochem. 78, 167-174

Geisler, N. (1983) Cold Spring Harbor Symp. 48, 717-729

Geisler, N., Plessmann, U. \& Weber, K. (1982) Nature (London) 296, 448-450

Goldstein, M. E., Sternberger, L. A. \& Sternberger, N. H. (1983) Proc. Natl. Acad. Sci. U.S.A. 80, 3101-3105

Hirokawa, N. (1982) J. Cell Biol. 94, 129-142

Jones, S. M. \& Williams, R. C. (1982) J. Biol. Chem. 257, 9902-9905

Received 5 July 1985/18 November 1985; accepted 5 December 1985
Julien, J. P. \& Mushynski, W. E. (1982) J. Biol. Chem. 257, $10467-10470$

Julien, J. P., Smoluk, G. D. \& Mushunski, W. E. (1983) Biochim. Biophys. Acta 755, 25-31

Kelly, P. T. \& Luttges, M. W. (1976) J. Neurochem. 27, $1163-1172$

Laemmli, U. K. (1970) Nature (London) 227, 680-685

Lazarides, E. (1982) Annu. Rev. Biochem. 51, 219-250

Lennon, A. M., Chantoux, F., Osty, J. \& Francon, J. (1983) Biochem. Biophys. Res. Commun. 116, 901-908

Leterrier, J. F., Liem, R. K. H. \& Shelanski, M. L. (1981) J. Cell. Biol. 95, 755-760

Leterrier, J. F., Liem, R. K. H. \& Shelanski, M. L. (1982) J. Cell Biol. 95, 982-986

Liem, R. K. H., Pachter, J. W., Napolitano, E., Moraru, E. \& Heimann, R. (1984) Ann. N.Y. Acad. Sci. 455, 492-508

Lou Vallano, M., Bucklolz, M. \& Delorenzo, R. J. (1985) Biochim. Biophys. Acta 130, 957-963

Minami, Y., Murofushi, H. \& Sakai (1982) J. Biochem. (Tokyo) 92, 889-898

Nagele, R. G. \& Roisen, F. J. (1982) Brain Res. 253, 31-37

Nestler, E. J. \& Greengard, P. (1983) Nature (London) 305, 583-588

Nixon, R. A., Brown, B. A. \& Marotta, C. A. (1982) J. Cell. Biol. 94, 150-158

Pachter, J. S., Napolitano, E. W., Chin, S. S. M. \& Liem, R. K. H. (1984) J. Cell. Biol. 99, 321a-325a

Runge, M. S., Laue, T. M., Yphantis, D. A., Lifsics, M. R., Saito, A., Altin, M., Reinke, K. \& Williams, R. C. (1981a) Proc. Natl. Acad. Sci. U.S.A. 78, 1431-1435

Runge, M. S., El Maghrabi, M. R., Claus, T. H., Pilkis, S. J. \& Williams, R. C. (1981b) Biochemistry 20, 175-180

Shecket, G. \& Lasek, R. J. (1982) J. Biol. Chem. 257, 4788-4795

Shelanski, M. L., Gaskin, F. \& Cantor, R. C. (1973) Proc. Natl. Acad. Sci. U.S.A. 70, 765-768

Steinert, P. N., Rice, R. H., Ropp, D. R., Trus, B. L. \& Steven, A. C. (1983) Nature (London) 302, 794-800

Toru-Delbauffe, D. \& Pierre, M. (1983) FEBS Lett. 162, 230-234

Towbin, H., Staehelin, T. \& Gordon, J. (1979) Proc. Natl. Acad. Sci. U.S.A. 76, 4350-4354

Zimmerman, U. J. P. \& Schlaepfer, W. W. (1985) Biochem. Biophys. Acta 129, 804-811 